\title{
Effect of cadmium on the expression levels of interleukin-1 $\alpha$ and interleukin-10 cytokines in human lung cells
}

\author{
CAROLINE ODEWUMI $^{1}$, LEKAN M. LATINWO ${ }^{1}$, ANDRE SINCLAIR ${ }^{1}$, VEERA L.D. BADISA ${ }^{1}$, \\ AHKINYALA ABDULLAH ${ }^{2}$ and RAMESH B. BADISA ${ }^{3}$ \\ ${ }^{1}$ Department of Biological Sciences, Florida A\&M University, Tallahassee, FL 32307; \\ ${ }^{2}$ Department of Integrated Environmental Science and Natural Science, School of Science Engineering and Math, \\ Bethune-Cookman University, Daytona Beach, FL 32114; ${ }^{3}$ Department of Basic Science, \\ College of Pharmacy and Pharmaceutical Sciences, Florida A\&M University, \\ Tallahassee, FL 32307, USA
}

Received August 26, 2014; Accepted May 19, 2015

DOI: $10.3892 / \mathrm{mmr} .2015 .4316$

\begin{abstract}
Cadmium is an environmentally hazardous metal, which causes toxicity in humans. Inhalation of cigarette smoke and industrial fumes containing cadmium are sources of cadmium exposure. It is responsible for the malfunction of various organs, leading to disease particularly in the lungs, liver and kidneys. In the present study, the effect of cadmium chloride $\left(\mathrm{CdCl}_{2}\right)$ on cell viability, and the expression levels of interleukin (IL)-1 $\alpha$ and IL-10 cytokines at various concentrations and incubation durations were assessed in MRC-9 human normal lung and A549 human lung cancer cells to elucidate the mechanism of cadmium toxicity. Cell viability was measured using a crystal violet dye binding assay. The expression levels of the cytokines were measured by cytokine specific enzyme-linked immunosorbent assay kits. The viability assay results revealed higher sensitivity of the A549 lung cancer cells to $\mathrm{CdCl}_{2}$ compared with the normal MRC-9 lung cells. In the normal MRC-9 lung cells, higher expression levels of the cytokines were observed at the lowest $\mathrm{CdCl}_{2}$ concentration at a shorter exposure time compared with the lung cancer cells. Higher levels of the cytokines were observed in the A549 lung cancer cells at all other times and concentrations compared with the MRC-9 cells, indicating higher levels of inflammation. The cytokine levels were reduced at higher $\mathrm{CdCl}_{2}$ concentrations and longer exposure durations, demonstrating the toxic effect of cadmium. The results indicated that $\mathrm{CdCl}_{2}$ affected the expression levels of the cytokines and led to cytotoxicity in human lung cells, and suggested that compounds which reduce inflammation may prevent cadmium toxicity.
\end{abstract}

Correspondence to: Dr Caroline Odewumi, Department of Biological Sciences, Florida A\&M University, 1530 SMLK Boulevard, Tallahassee, FL 32307, USA

E-mail: caroline.odewumi@famu.edu

Key words: cadmium, cytokines, interleukin-1 $\alpha$, interleukin-10, viability

\section{Introduction}

Cadmium is a hazardous environmental pollutant with economic value, however no known biological function. It is an industrial toxicant, which has been classified as a type I carcinogen $(1,2)$. It is a highly reactive metal and complexes with ligands to form different compounds, which affect numerous biological molecules and organs (3). A significant quantity of cadmium is introduced into the environment through anthropogenic activities, including copper and nickel smelting, electroplating, galvanizing, nickel-cadmium battery production, welding, phosphate fertilizers, sewage sludge and cigarette smoke $(3,4)$. The toxicokinetics of cadmium depend on the form of cadmium, the dose, the time of exposure and the accumulation in the affected organ $(5,6)$. Cadmium can be observed in all organs of the body; however, the majority accumulates in the lungs, liver and kidney $(7,8)$. Although the level of cadmium exposure to humans is low, it can accumulate and remain in the system for 15-30 years (9-11), which is responsible for the toxicity in various organs. Cadmium molecular toxicity has been associated with various diseases, including tumor formation.

Our previous study investigated cadmium toxicity and the protective effect of different antioxidant or chelating compounds, which reduce the toxic effect of cadmium in liver cells (12-15). Inhalation is one of the predominant causes of cadmium exposure in humans and it has been reported to cause chronic inflammation and is responsible for various lung diseases (16-19). Cytokines are the predominant mediators of inflammation. Interleukin (IL)-1 $\alpha$ is an important pro-inflammatory cytokine, which regulates the expression levels of other cytokines and chemokines (20-22). Conversely, cells respond to various toxic insults by secreting different anti-inflammatory cytokines, including IL-10, for defense and repair mechanisms (23).

The aim of the present study was to measure the expression levels of the IL-1 $\alpha$ and IL-10 cytokines and to determine the viability of normal and cancerous human lung cells treated with various concentrations of cadmium chloride $\left(\mathrm{CdCl}_{2}\right)$ for different incubation periods in order to elucidate 
the mechanism of cadmium toxicity. The IL- $1 \alpha$ and IL-10 cytokines were selected as they were significantly upregulated following treatment with $75 \mu \mathrm{M} \mathrm{CdCl}_{2}$ after $24 \mathrm{~h}$ in our previous study using human A549 cancer cells (24).

\section{Materials and methods}

Chemicals. The F12 K medium, penicillin/streptomycin antibiotic solution (100X), fetal bovine serum (FBS), trypsin-EDTA solution (1X), amphotericin B $(1,000 \mathrm{X})$, phosphate-buffered saline without calcium and magnesium, $\mathrm{CdCl}_{2}, 25 \%$ glutaraldehyde and crystal violet were purchased from Sigma-Aldrich (St. Louis, MO, USA). The human IL-10 (cat. no. ELH-IL10-001) and human IL-1 $\alpha$ (cat. no. ELH-IL1alpha-001) enzyme-linked immunosorbent assay (ELISA) kits were purchased from Ray Biotech, Inc. (Norcross, GA, USA).

Maintenance of the cell lines. The human MRC-9 normal lung (cat. no. CCL-212) and human A549 lung cancer (cat. no. CCL-185) cell lines were purchased from the American Type Culture Collection (Manassas, VA, USA). The supplied frozen cells were cultured, according to the manufacturer's instructions. The cells were grown in $10 \mathrm{ml}$ minimum essential medium (American Type Culture Collection) (MRC-9) or F12K (A549) medium, containing $100 \mathrm{U} / \mathrm{ml}$ penicillin, $100 \mu \mathrm{g} / \mathrm{ml}$ streptomycin, $0.025 \mu \mathrm{g} / \mathrm{ml}$ amphotericin $\mathrm{B}$ and $10 \% \mathrm{FBS}$ in T-75 $\mathrm{cm}^{2}$ tissue culture flasks at $37^{\circ} \mathrm{C}$ in a $5 \% \mathrm{CO}_{2}$ incubator (Nuaire Co., Plymouth, MN, USA).

Crystal violet viability test. The viability test was performed as previously reported (25). Briefly, to investigate the effect of $\mathrm{CdCl}_{2}$ on the viability of the cells, $\sim 1 \times 10^{5}$ A549 lung cancer cells or $5 \times 10^{4}$ normal MRC-9 lung cells were plated into each well of a 24-well tissue culture plate and allowed to stabilize overnight in a $5 \% \mathrm{CO}_{2}$ incubator at $37^{\circ} \mathrm{C}$. The cells were treated with $0,25,50,75,100,125,150$ or $200 \mu \mathrm{M} \mathrm{CdCl}_{2}$ in a final volume of $1 \mathrm{ml}$ in triplicate wells and were subsequently incubated for $24 \mathrm{~h}$ at $37^{\circ} \mathrm{C}$ in a $5 \% \mathrm{CO}_{2}$ incubator. Following incubation, the viability of the cells was measured. The median lethal dose $\left(\mathrm{LD}_{50}\right)$ value was calculated from the $\mathrm{LD}_{50}$ graph where the two lines meet, according to a previous study (26).

Preparation of cell extracts. A total of $\sim 3.9 \times 10^{6}$ A549 lung cancer cells or $1.95 \times 10^{6}$ normal MRC-9 lung cells were plated into T-75 $\mathrm{cm}^{2}$ flasks in complete medium. Each cell line was treated with $0,50,100$ or $150 \mu \mathrm{M} \mathrm{CdCl}_{2}$ in triplicate flasks for various durations $(0,6,12,18$ or $24 \mathrm{~h})$ and were incubated at $37^{\circ} \mathrm{C}$ at $5 \% \mathrm{CO}_{2}$. At the end of each treatment period, the cells were trypsinized and centrifuged at $1,350 \mathrm{x} \mathrm{g}$ for $5 \mathrm{~min}$. The cells were lysed in $1 \mathrm{ml}$ of $50 \mathrm{mM}$ potassium phosphate ( $\mathrm{pH}$ 7.0) lysis buffer, containing $0.1 \%$ Triton X-100, by homogenization in a vial on ice three times for $10 \mathrm{sec}$ using a polytron homogenizer (Pro Scientific, Inc., Oxford, CT, USA). The homogenate was subsequently transferred to an eppendorf tube and centrifuged at $12,740 \mathrm{x} \mathrm{g}$ for $10 \mathrm{~min}$ at $4^{\circ} \mathrm{C}$ to remove the lysed cell membrane debris. The supernatants were transferred into fresh tubes and the cell lysates were stored at $-20^{\circ} \mathrm{C}$ for cytokine analysis.
Protein estimation. The protein concentration of the cell lysates were determined using a Bicinchoninic Acid Protein Assay kit (Pierce Biotechnology, Inc., Rockford, IL, USA) with bovine serum albumin as a standard protein. The protein standards and working reagents were prepared, according to the manufacturer's instructions. In triplicate eppendorf tubes, $25 \mu 1$ standard or lysate sample were added. The working reagent (500 $\mu \mathrm{l})$ was added to each tube, incubated at $37^{\circ} \mathrm{C}$ for $30 \mathrm{~min}$ and was subsequently measured at $562 \mathrm{~nm}$ in a Beckman spectrophotometer (Beckman Coulter, Inc., Fullerton, CA, USA). The concentration of the lysate samples were determined using the standard curve.

ELISA. The human IL-1 $\alpha$ and IL-10 ELISA kits were purchased from Ray Biotech Inc. and used for the quantitative measurement of the expression levels of the cytokines in human lung cells. The ELISA was performed according to the manufacturer's instructions. The intensity of the color in the 96-well plate was measured at $450 \mathrm{~nm}$ using a plate reader (EL 800; Bio-Tek Instruments, Inc., Winooski, VT, USA).

Statistical analysis. The viability and cytokine assay results are presented as the mean \pm standard deviation $(n=3)$. All $\mathrm{CdCl}_{2}$-treated cell data are presented as a percentage value compared with the untreated control cells (100\%). The data were analyzed for significance by Dunnet's multiple comparison test, using GraphPad Prism software version 3.0 (GraphPad Software Inc., San Diego, CA, USA). P<0.05 was considered to indicate a statistically significant difference.

\section{Results}

Effect of $\mathrm{CdCl}_{2}$ on the cell viability of human MRC-9 normal lung and A549 cancer cells. The viability of the normal and cancerous lung cells exposed to various $\mathrm{CdCl}_{2}$ concentrations was demonstrated to be dose-dependent (Fig. 1). The viability of the normal lung MRC-9 cells was reduced by $6,11,11,44$, 55, 60 and 75\% (Fig. 1A), while the viability of the A594 lung cancer cells was decreased by $13,36,42,58,65,76$ and $81 \%$ (Fig. 1B) following $24 \mathrm{~h}$ treatment with 25, 50, 75, 100, 125, 150 and $200 \mu \mathrm{M} \mathrm{CdCl}_{2}$, respectively. The significant toxic effect of $\mathrm{CdCl}_{2}$ was observed at $25 \mu \mathrm{M} \mathrm{CdCl}_{2}$ in the A549 lung cancer cells, while the MRC-9 normal lung cells exhibited a significant decrease in viability at $50 \mu \mathrm{M} \mathrm{CdCl}_{2}$. The $\mathrm{LD}_{50}$ of $\mathrm{CdCl}_{2}$ was revealed to be $87.5 \mu \mathrm{M}$ in the $\mathrm{A} 549$ cells and $112.5 \mu \mathrm{M}$ in the MRC-9 cells. These results demonstrated the toxic effect of $\mathrm{CdCl}_{2}$ on normal human lung cells and lung cancer cells.

Effect of $\mathrm{CdCl}_{2}$ concentration and treatment duration on the expression levels of IL-1 $\alpha$ and IL-10 cytokines in human MRC-9 normal lung cells. The human MRC-9 normal lung cells were treated with different concentrations of $\mathrm{CdCl}_{2}(0,50$, 100 or $150 \mu \mathrm{M})$ for various durations $(6,12,18$ or $24 \mathrm{~h})$, and the expression levels of IL-1 $\alpha$ and IL-10 cytokines were measured. The cells treated with $50 \mu \mathrm{M} \mathrm{CdCl}_{2}$ for $6 \mathrm{~h}$ demonstrated the maximum expression levels of each cytokine (Fig. 2). The cytokine levels decreased with increasing concentration and duration (Fig. 2). The results clearly demonstrated that normal MRC-9 lung cells responded to the toxic effect of $\mathrm{CdCl}_{2}$ with high expression levels of the cytokines in the lysate at early time points and high concentrations and longer exposure durations 

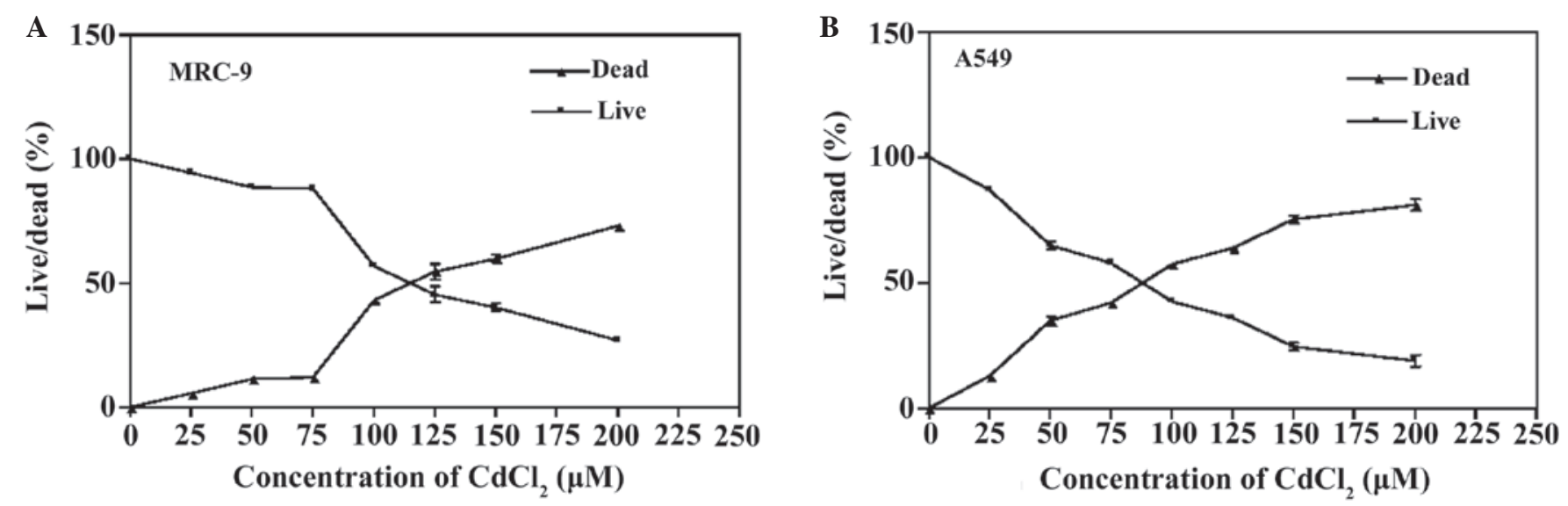

Figure 1 . Viability of the human normal lung cells and lung cancer cells following treatment with $\mathrm{CdCl}_{2}$. The cells were treated with $0,50,75,100,125,150$, 175 or $200 \mu \mathrm{M} \mathrm{CdCl}_{2}$ for $24 \mathrm{~h}$ and the viability was measured by a crystal violet assay. The graphs revealed the median lethal dose of CdCl${ }_{2}$, where $50 \%$ of the cells had died in the human (A) normal lung and (B) lung cancer cells.
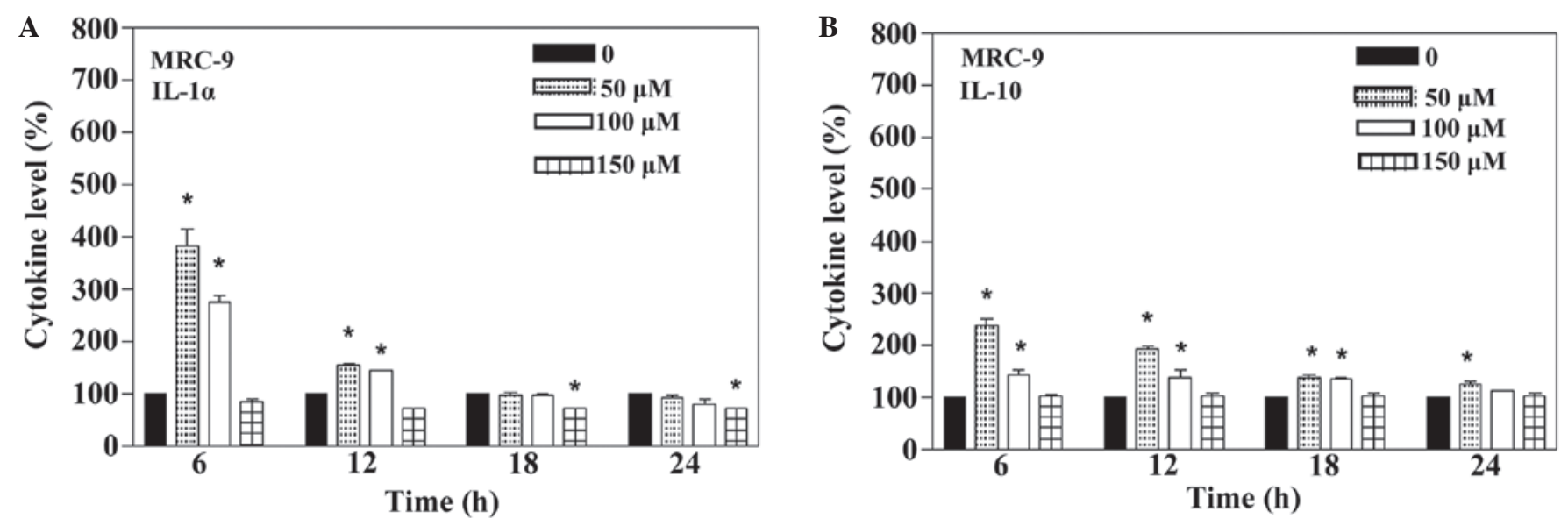

Figure 2. Expression levels of the cytokines, IL-1 $\alpha$ and IL-10, in the $\mathrm{CdCl}_{2}$-treated human MRC-9 normal lung cells. The cells were treated with 0,50 , 100 or $150 \mu \mathrm{M} \mathrm{CdCl}_{2}$ for $6,12,18$ or $24 \mathrm{~h}$ and the cytokine expression levels were measured by Ray Biotech, Inc. (Norcross, GA, USA) IL-1 $\alpha$ or IL-10 specific ELISA kits. The expression levels of (A) IL- $1 \alpha$ and (B) IL-10 were determined following treatment ( $\mathrm{P}<0.05$, compared with the control). IL, interleukin.

of $\mathrm{CdCl}_{2}$ demonstrated toxic effects on the expression levels of the cytokines.

Effect of the concentration of $\mathrm{CdCl}_{2}$ and duration on the expression level of $I L-1 \alpha$ and $I L-10$ cytokines in human A549 lung cancer cells. As shown in Fig. 3, the expression levels of IL- $1 \alpha$ and IL-10 cytokines in the A549 lung cancer cells treated with $0,50,100$ or $150 \mu \mathrm{M} \mathrm{CdCl}_{2}$ concentrations for 6,12 , 18 or $24 \mathrm{~h}$ were detected. The lung cancer cells treated with $50 \mu \mathrm{M} \mathrm{CdCl}_{2}$ for $12 \mathrm{~h}$ demonstrated the maximum expression of each cytokine, and the expression levels decreased as the duration of exposure and concentration of $\mathrm{CdCl}_{2}$ increased (Fig. 3). The results clearly demonstrated the response of the A549 lung cancer cells to the toxic effect of $\mathrm{CdCl}_{2}$, with high expression of cytokines at high concentrations and longer exposure durations of $\mathrm{CdCl}_{2}$, demonstrating the toxic effect on the expression of cytokines.

\section{Discussion}

The widespread industrial usage of cadmium presents a health risk directly and indirectly to humans and other living organisms. Industrial waste fumes, burning of fossil fuels and cigarette smoke are the predominant direct sources of cadmium exposure to humans. It is estimated that $90 \%$ of the inhaled cadmium particles are absorbed by lung tissue and cause pulmonary damage, emphysema and lung cancer (16-19). Organisms respond to xeno-biotics via inflammation and it is initiated through various signaling molecules, including cytokines, in the cells. To date, few investigations into the expression levels of the cytokines, IL-1 $\alpha$ (pro-inflammatory) and IL-10 (anti-inflammatory), have been reported (27). Therefore, elucidating the expression levels of IL- $1 \alpha$ and IL-10, and the cell viability at various $\mathrm{CdCl}_{2}$ concentrations and incubation durations in human MRC-9 normal lung and A549 lung cancer cells may provide an understanding of how lung cells response to cadmium toxicity.

The results indicated that A549 lung cancer cells were observed to be more sensitive to $\mathrm{CdCl}_{2}$ compared with the MRC-9 normal lung cells. The difference in their sensitivities was reflected in their $\mathrm{LD}_{50}$ values. The $\mathrm{LD}_{50}$ of $\mathrm{CdCl}_{2}$ for the normal MRC-9 lung cells was $112.5 \mu \mathrm{M}$, whereas the $\mathrm{LD}_{50}$ of the lung cancer cells was $87.5 \mu \mathrm{M}$ (Fig. 1). A previous study demonstrated that carcinomas contain significantly less 

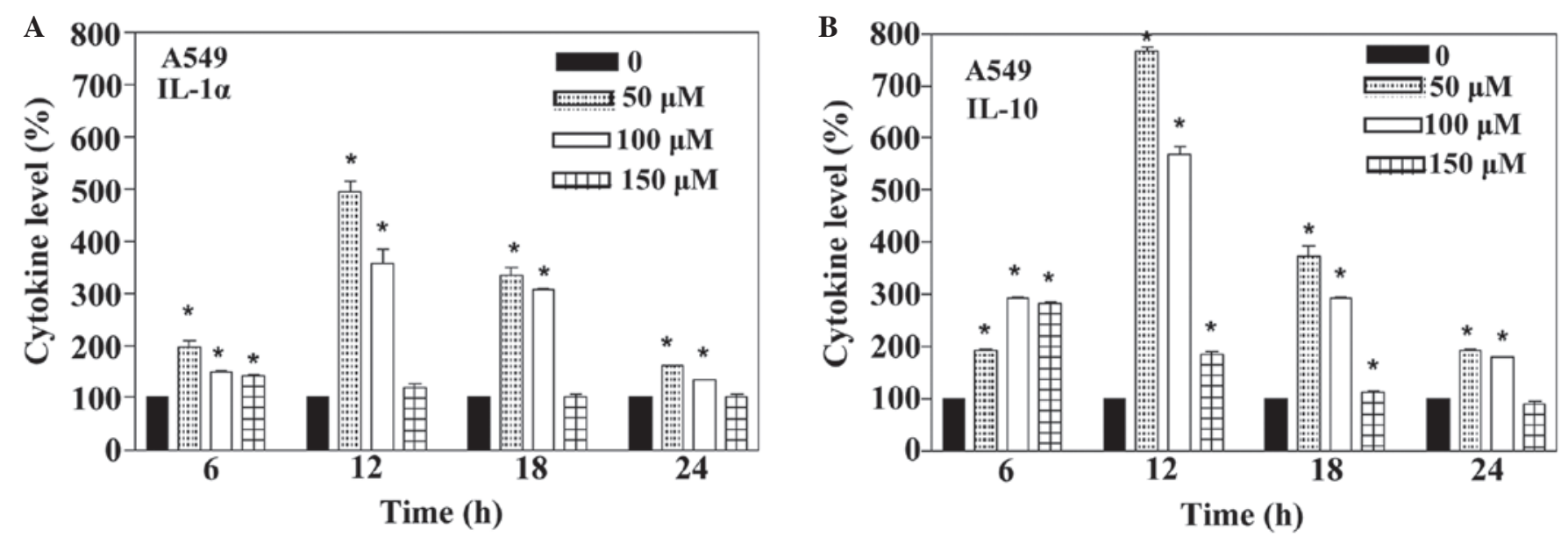

Figure 3. Expression levels of the cytokines, IL-1 $\alpha$ and IL-10, in the $\mathrm{CdCl}_{2}$-treated human A549 lung cancer cells. The cells were treated with 0 , 50 , 100 or $150 \mu \mathrm{M} \mathrm{CdCl}_{2}$ for $6,12,18$ or $24 \mathrm{~h}$ and the expression levels of the cytokines were measured by Ray Biotech, Inc. (Norcross, GA, USA) IL-1 $\alpha$ or IL-10 specific ELISA kits. The expression levels of (A) IL-1 $\alpha$ and (B) IL-10 were determined following the treatment ( ${ }^{*} \mathrm{P}<0.05$, compared with the control). IL, interleukin.

metallothionein compared with their corresponding normal cells (28). This may be one of the contributing factors for the higher sensitivity of cancer cells to cadmium toxicity, however, further investigation is required to prove this hypothesis.

Normal lung cells and the lung cancer cells revealed high expression levels of the IL-1 $\alpha$ and IL-10 cytokines following treatment with $\mathrm{CdCl}_{2}$ (Figs. 1 and 2). In a previous study (29), a significant increase in IL- $1 \alpha$ and IL-10 cytokines was observed in the tested cells, when human-derived bronchial epithelium was exposed to tobacco smoke components. Furthermore, other previous studies have revealed that cells release pro-inflammatory cytokines during inflammation, to activate the cytokine network and the secretion of anti-inflammatory cytokines $(30,31)$. The higher expression of cytokines, which lead to inflammation, may be responsible for the later cytotoxic effects in the cells, which lead to a decrease in viability, as observed in the present study (Fig. 1). This is supported by a previous study (32) demonstrating that high levels of pro-inflammatory cytokines due to cadmium exposure cause pathological conditions in a biological system.

When the cytokine levels were compared in the normal lung cells, a higher expression of pro-inflammatory cytokine, IL-1 $\alpha$, was observed compared with the anti-inflammatory cytokine, IL-10, at $6 \mathrm{~h}$ exposure (Fig. 2). A high level of IL-1 $\alpha$ cytokine in the cells exposed to xeno-biotics has been reported to inhibit the expression of metallothionein protein (33). In that previous study, IL- $1 \alpha$ inhibited the mRNA expression of metallothionein in endometrial stromal cells and amniotic cells treated with $\mathrm{CdCl}_{2}$. Based on the above report, the present study hypothesized that increased levels of IL-1 $\alpha$ may reduce the protein expression of metallothionein, which in turn leads to the increase in unbound $\mathrm{CdCl}_{2}$ in the cell, which may now damage biological molecules, including proteins, as shown by the decreased expression of IL-1 $\alpha$ and IL-10 observed in the present study (Fig. 2).

The expression pattern of the IL- $1 \alpha$ and IL-10 cytokines from the A549 cancer lung cells was different compared with the normal lung cells. The maximum levels of the IL- $1 \alpha$ and IL-10 cytokines were observed at a later period (12 h, Fig. 3) in the lung cancer cells compared with the normal cells $(6 \mathrm{~h}$,
Fig. 2). In addition, it was also observed that each cytokine was highly expressed in cancer cells compared with the normal cells treated with $\mathrm{CdCl}_{2}$ (Figs. 2 and 3). A similar observation was observed when the cytokine levels of patients with cancer were compared with the cytokine levels of normal individuals (34). The delayed expression and higher expression levels of the cytokines observed in cancer cells may be as a result of the malfunction of the cell regulatory mechanisms commonly observed in cancer cells.

Lung cancer cells demonstrated higher expression of the anti-inflammatory cytokine, IL-10, compared with the pro-inflammatory cytokine, IL-1 $\alpha$ (Fig. 3). This was consistent with our previously reported findings (24) and another previous study (35). IL-10 acts as anti-inflammatory cytokine and is also responsible for cell death. IL-10 cytokine has been demonstrated to decrease the translocation of nuclear factor- $\kappa \mathrm{B}$, which is important in increasing apoptotic markers, which later leads to apoptotic cell death (31). Therefore, the higher levels of IL-10 cytokine in the A549 lung cancer cells may be one of the reasons for the higher cytotoxicity caused by $\mathrm{CdCl}_{2}$ (Fig. 1).

In the present study, higher cadmium concentrations (100 and $150 \mu \mathrm{M}$ ) decreased the expression levels of the cytokines in the normal and cancer cells (Figs. 2 and 3). Higher concentrations of cadmium induced higher levels of reactive oxygen species, which degrade macromolecules, including proteins and DNA $(12,13,36)$. The low expression levels of the IL-1 $\alpha$ and IL-10 cytokines in each cell line may also be linked to the toxic effect of unbound cadmium in the cells, as a result of the lack of metallothionein protein. This result is consistent with a previous study, which reported inhibition of the expression of IL- $1 \alpha$ in rat hepatocytes following treatment with high concentrations of $\mathrm{CdCl}_{2}$ (32). In addition, longer exposure durations may also be a factor in causing higher toxicity, as decreased expression of cytokines were observed with increased incubation durations in the present study (Figs. 2 and 3). The longer exposure duration led to the accumulation of cadmium inside of the cell, which in turn causes decreased cytokine levels leading to cell death.

In conclusion, the viability result revealed that human A549 lung cancer cells exhibited higher sensitivity to $\mathrm{CdCl}_{2}$ compared with the normal MRC-9 lung cells. Furthermore, 
the cells demonstrated a differential expression of the cytokines in response to $\mathrm{CdCl}_{2}$. The maximum cytokine levels were observed in the normal MRC-9 lung cells at an early incubation time (6 h) compared with the lung cancer cells $(12 \mathrm{~h})$, demonstrating an early immune response of normal lung cells. The present study clearly demonstrated the effect of $\mathrm{CdCl}_{2}$ on the expression levels of cytokines in lung cells and suggested that compounds, which activate the cytokines and reduce inflammation, may prevent cadmium toxicity.

\section{Acknowledgements}

This study was supported by the FAMU Title III, Department of Education (grant no. DOEHBGIPO31B40108-08) and the RCMI, National Institute of Health (grant nos. G12RR03020 and G12D007582).

\section{References}

1. International agency for research on cancer (IARC): Monographs on the Evaluation of the Carcinogenic Risks to Humans, Beryllium, Cadmium, Mercury and Exposures in the Glass Manufacturing industry. In: IARC Scientific Publications, Lyon, France. pp119-238, 1993.

2. Goering PL, Waalkes MP and Klaassen CD: Toxicology of cadmium. Toxicology of metals: Biochemical Aspects. In: Goyer RA and Cherias M, (Eds.) Handb Exp Pharmacol 15 : 189-214, 1995.

3. Agency for Toxic Substances and Disease Registry (ATSDR): Toxicological Profile for Cadmium. Atlanta, GA: U.S Department of Health and Human Services, Public Health Service 1-512, 2012

4. Joseph P: Mechanisms of cadmium carcinogenesis. Toxicol Appl Pharmacol 238: 272-279, 2009.

5. Chin TA and Templeton DM: Protective elevations of glutathione and metallothionein in cadmium-exposed mesangial cells. Toxicology 77: 145-156, 1993.

6. Bridges CC and Zalups RK: Molecular and ionic mimicry and the transport of toxic metals. Toxicol Appl Pharmacol 204 274-308, 2005.

7. Habeebu SS, Liu J and Klaassen CD: Cadmium-induced apoptosis in mouse liver. Toxicol Appl Pharmacol 149: 203-209, 1998.

8. Rikans LE and Yamano T: Mechanisms of cadmium-mediated acute hepatotoxicity. J Biochem Mol Toxicol 14: 110-117, 2000.

9. Jin T, Lu J and Nordberg M: Toxicokinetics and biochemistry of cadmium with special emphasis on the role of metallothionein Neurotoxicology 19: 529-535, 1998.

10. Waalkes MP, Anver M and Diwan BA: Carcinogenic effects of cadmium in the noble (NBL/Cr) rat: Induction of pituitary, testicular and injection site tumors and intraepithelial proliferative lesions of the dorsolateral prostate. Toxicol Sci 52: 154-161, 1999.

11. Boujelben M, Ghorbel F, Vincent C, Makni-Ayadi F, Guermazi F, Croute F and El-Feki A: Lipid peroxidation and HSP72/73 expression in rat following cadmium chloride administration: Interactions of magnesium supplementation. Exp Toxicol Pathol 57: 437-443, 2006.

12. Ikediobi CO, Badisa VL, Ayuk-Takem LT, Latinwo LM and West J: Response of antioxidant enzymes and redox metabolites to cadmium-induced oxidative stress in CRL-1439 normal rat liver cells. Int J Mol Med 14: 87-92, 2004.

13. Badisa VL, Latinwo LM, Odewumi CO, Ikediobi CO, Badisa RB Brooks-Walter A, Lambert AT and Nwoga J: Cytotoxicity and stress gene microarray analysis in cadmium-exposed CRL-1439 normal rat liver cells. Int J Mol Med 22: 213-219, 2008.

14. Odewumi CO, Badisa VL, Le UT, Latinwo LM, Ikediobi CO, Badisa RB and Darling-Reed SF: Protective effects of $\mathrm{N}$-acetylcysteine against cadmium-induced damage in cultured rat normal liver cells. Int J Mol Med 27: 243-248, 2011.

15. Odewumi CO, Buggs R, Badisa VL, Latinwo LM, Badisa RB, Ikediobi CO, Darling-Reed SF and Owens MA: Mitigative action of monoisoamy 1-2,3-dimercaptosuccinate (MiADMS) against cadmium-induced damage in cultured rat normal liver cells. Toxicol In Vitro 25: 1733-1739, 2011.
16. Navarro Silvera SA and Rohan TE: Trace elements and cancer risk: A review of the epidemiologic evidence. Cancer Causes Control 18: 7-27, 2007.

17. Straif K, Benbrahim-Tallaa L, Baan R, Grosse Y, Secretan B, El Ghissassi F, Bouvard V, Guha N, Freeman C, Galichet L, et al; WHO International Agency for Research on Cancer Monograph Working Group: A review of human Carcinogens part C: Metals, arsenic, dusts and fibres. Lancet Oncol 10: 453-454, 2009.

18. Kundu S, Sengupta S and Bhattacharyya A: EGFR upregulates inflammatory and proliferative responses in human lung adenocarcinoma cell line (A549), induced by lower dose of cadmium chloride. Inhal Toxicol 23: 339-348, 2011.

19. Rogalska J, Pilat-Marcinkiewicz B and Brzóska MM: Protective effect of zinc against cadmium hepatotoxicity depends on this bioelement intake and level of cadmium exposure: A study in a rat model. Chem Biol Interact 193: 191-203, 2011.

20. Shimabukuro DW, Sawa T and Gropper MA: Injury and repair in lung and airways. Crit. Care Med 31 (8 Suppl): S524-S531, 2003.

21. Grivennikov SI, Kuprash DV, Liu ZG and Nedospasov SA: Intracellular signals and events activated by cytokines of the tumor necrosis factor superfamily: From simple paradigms to complex mechanisms. Int Rev Cytol 252: 129-161, 2006

22. Barksby HE, Lea SR, Preshaw PM and Taylor JJ: The expanding family of interleukin-1 cytokines and their role in destructive inflammatory disorders. Clin Exp Immunol 149: 217-225, 2007.

23. Trandem K, Jin Q, Weiss KA, James BR, Zhao J and Perlman S: Virally expressed interleukin-10 ameliorates acute encephalomyelitis and chronic demyelination in coronavirus-infected mice. J Virol 85: 6822-6831, 2011.

24. Odewumi CO, Fils-Aime S, Badisa VL, Latinwo LM, Ruden ML, Ikediobi C and Badisa RB: Chemoprotective effect of monoisoamyl 2,3-dimercaptosuccinate (MiADMS) on cytokines expression in cadmium chloride treated human lung cells. Environ Toxicol 30: 704-711, 2015.

25. Badisa RB, Tzakou O, Couladis M and Pilarinou E: Cytotoxic activities of some Greek Labiatae herbs. Phytother Res 17: 472-476, 2003.

26. Ipsen J and Feigl P: Bancroft's Introduction to Biostatistics (Second Edition), Harper and Row, New York. pp164, 1970.

27. Krocova Z, Macela A, Kroca M and Hernychova L: The immunomodulatory effect(s) of lead and cadmium on the cells of immune system in vitro. Toxicol In Vitro 14: 33-40, 2000

28. Janssen AM, van Duijn W, Kubben FJ, Griffioen G, Lamers CB, van Krieken JH, van de Velde CJ and Verspaget HW: Prognostic significance of metallothionein in human gastrointestinal cancer. Clin Cancer Res 8: 1889-1896, 2002.

29. Balharry D, Sexton K and BéruBé KA: An in vitro approach to assess the toxicity of inhaled tobacco smoke components: Nicotine, cadmium, formaldehyde and urethane. Toxicology 244: 66-76, 2008

30. Bergman M, Djaldetti M, Salman H and Bessler H: Inflammation and colorectal cancer: Does aspirin affect the interaction between cancer and immune cells? Inflammation 34: 22-28, 2011.

31. Romoser AA, Chen PL, Berg JM, Seabury C, Ivanov I, Criscitiello MF and Sayes CM: Quantum dots trigger immunomodulation of the NFKB pathway in human skin cells. Mol Immunol 48: 1349-1359, 2011.

32. Kayama F, Yoshida T, Elwell MR and Luster MI: Role of tumor necrosis factor-alpha in cadmium-induced hepatotoxicity. Toxicol Appl Pharmacol 131: 224-234, 1995.

33. Kawano Y, Furukawa Y, Kawano Y, Abe W, Hirakawa T and Narahara H: Cadmium chloride induces the expression of metallothionein mRNA by endometrial stromal cells and amnion-derived (WISH) cells. Gynecol Obstet Invest 71: 240-244, 2011.

34. Katsumata N, Eguchi K, Fukuda M, Yamamoto N, Ohe Y, Oshita F, Tamura T, Shinkai T and Saijo N: Serum levels of cytokines in patients with untreated primary lung cancer. Clin Cancer Res 2: 553-559, 1996.

35. Bermúdez-Morales VH, Peralta-Zaragoza O, Alcocer-González JM, Moreno J and Madrid-Marina V: IL-10 expression is regulated by HPV E2 protein in cervical cancer cells. Mol Med Report 4: 369-375, 2011.

36. Thévenod $\mathrm{F}$ and Lee WK: Cadmium and cellular signaling cascades: Interactions between cell death and survival pathways. Arch Toxicol 87: 1743-1786, 2013. 